\title{
Preface: special section of papers dealing with overdeepened basins and valleys in the alpine realm
}

\author{
Markus Fiebig • Frank Preusser • Kurt Decker • \\ Christian Schlüchter
}

Published online: 2 December 2010

(c) Swiss Geological Society 2010

Overdeepened basins and valleys are common features in most regions that were glaciated during the Quaternary. Such structures are known from areas formerly covered by the Laurentian and Scandinavian Ice Sheet as well as for some parts of the Alps and their foreland. The phenomenon describes subsurface geomorphic features, erosionally cut into bedrock and later filled up by sediments. These structures can reach a depth of several hundred metres below the present valley floor. The sedimentary fillings of overdeepened basins and valleys are of particular interest for applied geosciences, for example in the context of groundwater resource management and subsurface constructions (i.e. tunnels). Recently, the topic of when and how overdeepening occurred in the past has gained additional attention with regard to the long-term stability of nuclear waste disposals, especially in Switzerland. In this context, it is important to note that relatively little research focussed on this issue during the past three decades. The last overview on the topic was a compilation of papers

\footnotetext{
M. Fiebig ( $\square)$

Institute of Applied Geology, University of Natural Resources and Life sciences, Peter Jordan-Str. 70, 1190 Vienna, Austria

e-mail: markus.fiebig@boku.ac.at

F. Preusser · C. Schlüchter

Institute of Geological Sciences, University of Bern,

Baltzerstr. 1-3, 3012 Bern, Switzerland

e-mail: frank.preusser@geo.unibe.ch

C. Schlüchter

e-mail: christian.schluechter@geo.unibe.ch

K. Decker

Department for Geodynamics and Sedimentology,

University Vienna, Althanstr. 14, 1090 Vienna, Austria

e-mail: kurt.decker@univie.ac.at
}

published in a special issue of the journal Eiszeitalter und Gegenwart in 1979.

This special section in the present issue of the Swiss Journal of Geosciences comprises six papers related to the phenomenon of overdeepening in the Alps. The article by F. Preusser, J. Reitner and Ch. Schlüchter summarises the areal distribution and geometry, reviews the present knowledge of the age of formation, and discusses possible processes responsible for overdeepened features. P. Jordan analyses the overdeepened structures in the foreland of the Swiss Alps using a Digital Elevation Model of bedrock surface based on outcrop and borehole data. It is shown that overdeepening mainly occurs within the limits of the Last Glaciation Maximum (LGM), but with a few overdeepened valleys and basin reaching beyond. M. Dürst Stucki, R. Reber and F. Schlunegger interpret the buried valleys beneath the city of Bern as a network of tunnel valleys originating from subglacial high pressure melt water erosion. Valleys found in the surrounding Molasse uplands are regarded to represent proglacial melt water paths. The subsurface characteristics of three deep valleys from the Eastern Alps are investigated by E. Brückl, J. Brückl, W. Chwatal and Ch. Ullrich using different geophysical surveys. The authors conclude that deep erosion is not related to basal shear stress and that glacial confluence situations did in these examples not lead to important overdeepening. Rather, it is suggested that deep erosion was related to high pressured melt water at the glacier bed in settings of already tectonically weakened bedrock. The upper part of the sedimentary filling of the overdeepened Wehntal in northern Switzerland is analysed by F. Anselmetti, R. Drescher-Schneider, H. Furrer, H. R. Graf, S. Lowick, F. Preusser and M. Riedi revealing that it reaches back to at least 180,000 a. It is shown that the penultimate glaciation (pre-dating the Last Interglacial) may have reached the area 
but apparently did not cause the initial erosion of the basin. As a consequence, the age for glacial overdeepening is in this case considered to be $>200,000$ a. J. Reitner, W. Gruber, A. Römer and R. Morawetz study the basin fill of the inneralpine basin of Hopfgarten to reveal its formation in relation to palaeo-ice flow directions and tectonics. They conclude that glacial erosion during the LGM was limited to the phase of ice build-up due to the geomorphic and glaciological setting. During older glaciations, different geometric settings, in particular the altitude of transfluences, may explain the more intense erosion at times.
We would like to express our thanks to National Cooperative for the Disposal of Radioactive Waste (nagra) for generously supporting the printing costs. In particular we acknowledge the help by M. Schnellmann for his support. We would also like to thank the several people who helped with the volume: H. Pfalz-Schwingenschlögl for graphic design, the reviewers for their helpful suggestions and comments, and the editorial team, especially S. Bucher, for offering the possibility to publish this special section. 